Tạp chi Khoa học và Công nghệ, Số 44, 2020

\title{
PHÂN LẬP VÀ KHẢO SÁT ĐIỀU KIỆn SINH TỔNG HợP AMYLASE CỦA XẠ KHUẦN RB-XK3
}

\author{
NGUYẼ̃N THİ DIỆU HẠNH ${ }^{1}$, NGUYẼ̃N THI THANH THÚY ${ }^{1}$, BÙI THI LUY ẾN ${ }^{2}$, NGUYẼ̃N \\ THANH HẢ̇ ${ }^{2}$, HỨA TRƯỜNG CHINH ${ }^{1}$, ĐẠNG BÍCH NGẦN ${ }^{1}$, NGUYẼ̃N NGỌC ẨN ${ }^{1}$, \\ PHAM TÂंN VIÊT ${ }^{*}$ \\ ${ }^{I}$ Viện Công nghệ Sinh học và Thưc phẩm, Truờng Đại học Công Nghiệp Tp. Hồ Chi Minh, 12 Nguyễn \\ Văn Bảo, Gò Vấp, Tp. Hồ Chí Minh. \\ ${ }^{2}$ Truờng Đại học Khoa học Tự nhiên, Đại học Quốc gia Tp. Hồ Chí Minh, 227 Nguyễn Văn Cù, quận 5, \\ Tp. Hồ Chí Minh. \\ phamtanviet@iuh.edu.vn
}

Tóm tắt: Vi sinh vật có vai trò quan trọng trong việc phân hủy các hợp chất hữu cơ trong tự nhiên và là đối tượng cho việc sản xuất enzyme trên thế giới. Trong đó, amylase là một trong ba enzyme được sử dụng nhiều nhất trên thị trường enzyme công nghiệp và việc tìm kiếm các đối tượng vi sinh vật sản xuất amylase mạnh và có khả năng hoạt động tốt trong các điều kiện cực đoan là cần thiết, đặc biệt xạ khuẩn là đối tượng tiềm năng cho sự sản xuất amylase công nghiệp. Trong nghiên cứu này, 23 chủng xạ khuẩn đã được phân lập từ nhiều mẫu đất khác nhau, trong đó chủng xạ khuẩn RB-XK3 đã được tuyển chọn và định danh thuộc loài Streptomyces canus. Chủng xạ khuẩn này thể hiện khả năng sinh tổng hợp amylase tốt trong môi trường Gause II chứa $1 \%$ cơ chất tinh bột và $0,5 \% \mathrm{NH}_{4} \mathrm{NO}_{3}$ với $\mathrm{pH} 8,0$ tại $37^{\circ} \mathrm{C}$ trong thời gian lên men là 96 giờ. Chủng xạ khuẩn RB-XK3 cho thấy tiềm năng sản xuất amylase trong môi trường kiềm thay vì trung tính như các chủng xạ khuẩn khác và có thể ứng dụng trong nhiều lĩnh vực khác nhau.

Từ khóa: Streptomyces, amylase, enzyme ngoại bào, phân hủy tinh bột, điều kiện lên men

\section{ISOLATION AND SCREENING OF AMYLASE PRODUCTION OF ACTINOMYCES RB-XK3}

\begin{abstract}
Microorganisms play an important role in the breakdown of organic compounds in nature and are the object of enzyme production in the world. In particular, amylase is one of the three largest used groups in the industrial enzymes, and it is always necessary to select high amylase-producing microorganisms that can work under extreme conditions. Notably, actinomycetes are the potential targets for industrial amylase production. In this study, 23 strains of actinomycetes were isolated from many different soil samples, of which RB-XK3 was selected and identified as Streptomyces canus. This strain showed high amylase biosynthesis in Gause II medium containing $1 \%$ starch substrate and $0.5 \% \mathrm{NH}_{4} \mathrm{NO}_{3}$ with $\mathrm{pH} 8.0$ at $37^{\circ} \mathrm{C}$ for 96 hours. The RB-XK3 strain shows superior potential to produce amylase in an alkaline environment instead of the neutral one like other actinomycetes and thus can be applied in many different fields.
\end{abstract}

Keywords: Streptomyces, amylase, extracellular enzyme, starch degradation, fermentation conditions

\section{GIÓI THIẸU}

Amylase là nhóm enzyme quan trọng có khả năng thủy giải tinh bột tạo thành các loại đường khác nhau như fructose, glucose, maltose và các dextrin trung gian. Amylase được ứng dụng rộng rãi trong nhiều lĩnh vực khác nhau như công nghiệp thực phẩm, các ngành công nghệ lển men, dệt may và công nghệ sản xuất giấy $[1,2]$. Amylase được sử dụng thành công trong quá trình đường hóa tinh bột, trong công nghệ sản xuất rượu bia, cải thiện chất lượng bột trong công nghệ làm bánh và là thành phần trong công nghệ giặt tẩy [3-5]. Ngoài ra, nhiều nghiên cứu cũng đã cho thấy amylase còn được ứng dụng trong y học, công nghệ sinh học và hóa học $[5,6]$. Amylase là một trong ba nhóm enzyme được sử dụng nhiều nhất trong các enzyme công nghiệp, chiếm khoảng 25-33\% thị trường enzyme trên toàn thế giới [7]. Amylase được thu nhận từ nhiều nguồn khác nhau như thực vật, động vật, vi sinh vật và chủ yếu là được sản xuất từ vi sinh vật. Amylase vi sinh vật đáp ứng được nhu cầu công nghiệp và có thể gia tăng sự tổng hợp enzyme bằng các kỹ thuật di truyền, phương pháp nuôi cấy liên tục, cảm ứng và tối ưu hóa các điều kiện sinh 
trưởng [8]. Các chủng vi sinh vật thường được sử dụng để sản xuất amylase thuộc chi Bacillus, Streptomyces, Micrococcus, Pseudomonas, Arthrobacter, Escherichia, Proteus, Aspergillus và Serratia, trong đó các chủng xạ khuẩn thuộc chi Streptomyces ngày càng được quan tâm [5, 9-12].

Streptomyces là nhóm vi sinh vật quan trọng có hiệu quả kinh tế cao thuộc họ actinobacteria. Các chủng xạ khuẩn Streptomyces là đối tượng trong sản xuất khoảng $50 \%$ các hợp chất trao đổi thứ cấp, đặc biệt là các chất kháng sinh, kháng khối u, các enzyme và các chất ức chế enzyme, các hợp chất kháng khuẩn và kháng oxy hóa, các chất điều hòa thực vật và vitamin [13-15]. Streptomyces tham gia vào việc sản xuất nhiều loại enzyme khác nhau và đóng vai trò quan trọng trong việc phân hủy các hợp chất hữu cơ như cellulase, protease, keratinase, amylase, xylanase, lipase, chitinase, pectinase [5]. Với các đặc tính chịu nhiệt và chịu kiềm cao, việc sản xuất amylase từ xạ khuẩn ngày càng được quan tâm. Các amylase chiu nhiệt được sản xuất từ xạ khuẩn được ứng dụng dễ dàng trong nhiều ngành công nghiệp khác nhau [5]. Do đó, việc phân lập và chọn lọc các chủng xạ khuẩn có khả năng sinh tổng hợp amylase mạnh cũng như tối ưu hóa các điều kiện sản xuất amylase từ các chủng xạ khuẩn được nghiên cứu nhiều trong những năm gần đây [16-19].

Trong nghiên cứu này, chúng tôi đã phân lập, tuyển chọn và định danh chủng xạ khuẩn có khả năng tổng hợp amylase ngoại bào có hoạt tính cao và xác định các điều kiện thích hợp cho quá trình sinh tổng hợp amylase của chủng xạ khuẩn tuyển chọn được. Nghiên cứu này tạo cơ sở cho việc sản xuất amylase ngoại bào cũng như ứng dụng trong việc tạo chế phẩm vi sinh có khả năng phân hủy tinh bột để ứng dụng trong các lĩnh vực khác nhau.

\section{VẠT LIÊUU \& PHƯƠNG PHÁP NGHIÊN CỨU}

\subsection{Phân lập và tuyển chọn xạ khuẩn sinh tổng hợp amylase}

Các mẫu đất được thu thập từ nhiều địa phương khác nhau trên tỉnh Tiền Giang và Bến Tre. Mẫu đất sau đó được pha loãng trong nước muối sinh lý và trải trên môi trường thạch Gause $\mathrm{I}(20,0 \mathrm{~g}$ tinh bột tan; 0,5 $\mathrm{g} \mathrm{MgSO}_{4} \cdot 7 \mathrm{H}_{2} \mathrm{O} ; 3,0 \mathrm{~g} \mathrm{~K}_{2} \mathrm{HPO}_{4} ; 1,0 \mathrm{~g} \mathrm{KNO}_{3} ; 0,5 \mathrm{~g} \mathrm{NaCl} ; 0,1 \mathrm{~g} \mathrm{FeSO}_{4} ; 20,0 \mathrm{~g}$ agar; nước cất vừa đủ 1 lít; $\mathrm{pH} 7,2-7,4)$ ủ ở $37^{\circ} \mathrm{C}$ trong $5-10$ ngày. Các khuẩn lạc riêng rẽ có các đặc điểm đặc trưng của xạ khuẩn có khả năng tạo vòng phân giải tinh bột khi có sự hiện diện của dung dịch lugol được chọn và cấy ria liên tiếp 3 lần trong cùng môi trường và điều kiện như trên để làm thuần. Các khuẩn lạc sau làm thuần được giữ giống trong glycerol $20 \%$ tại $-46^{\circ} \mathrm{C}$ cho các thí nghiệm tiếp theo.

\section{2 Đánh giá sơ bộ khả năng sinh tổng hợp amylase}

Khả năng sinh tổng hợp amylase của các chủng xạ khuẩn được đánh giá sơ bộ thông qua vòng phân giải tinh bột trên môi trường thạch Gause $\mathrm{I}$ khi có sự hiện diện của dung dịch lugol. Các chủng xạ khuẩn được nuôi cấy trong môi trường Gause $\mathrm{I}$ ở $37^{\circ} \mathrm{C}$ trong 10 ngày. Sau thời gian nuôi ủ, vòng phân giải được kiểm tra bằng thuốc thử lugol. Khả năng sản sinh amylase để phân giải tinh bột của các chủng xạ khuẩn được xác định bằng cách so sánh độ lớn vòng phân giải $\mathrm{A}=\mathrm{D}-\mathrm{d}$ với $\mathrm{D}$ là đường kính vòng phân giải và $\mathrm{d}$ là đường kính khuẩn lạc của xạ khuẩn. Chủng xạ khuẩn có khả năng sinh tổng hợp amylase mạnh nhất sẽ được chọn để nghiên cứu các điều kiện nuôi cấy thích hợp cho sự sinh tổng hợp amylase ngoại bào.

\section{3 Định danh xạ khuẩn}

Căn cứ vào kết quả khảo sát sơ bộ về khả năng sinh tổng hợp amylase, chủng xạ khuẩn được chọn sẽ được nuôi trên môi trường Gause I trong 10 ngày ở $37^{\circ} \mathrm{C}$ và quan sát hình thái đại thể. Cấu trúc cuống sinh bào tử được quan sát trên tiêu bản phòng ẩm bằng kính hiển vi ở độ phóng đại 1000 lần. Chủng xạ khuẩn được định danh ở mức phân tử bằng phương pháp giải trình tự đoạn gen 16S-rRNA với cặp mồi 27F 5'-AGAGTTTGATCCTGGCTCAG-3' và 1492R 5'-GGTTACCTTGTTACGACTT-3' và phương trình PCR như sau $95^{\circ} \mathrm{C}-5$ phút, 30 chu kỳ tiếp theo $\left(95^{\circ} \mathrm{C}-30\right.$ giây; $55^{\circ} \mathrm{C}-40$ giây; $72^{\circ} \mathrm{C}-90$ giây) và $72^{\circ} \mathrm{C}-5$ phút bởi công ty Nam Khoa Biotek (793/62 Trần Xuân Hưng, Quận 7, Hồ Chí Minh) và kết quả giải trình tự được so sánh với cơ sở dữ liệu 16S-rRNA của xạ khuẩn có sẵn trên National Center for Biotechnology Information (NCBI) bằng công cụ BLASTN (https://blast.ncbi.nlm.nih.gov/Blast.cgi). Kết quả giải trình tự 2 chiều của vùng trình tự $16 \mathrm{~S}$ ribosomal RNA được kiểm tra độ chính xác và thiết lập trình tự consensus bằng phần mềm FinchTV và Seaview. Các trình tự được sắp gióng bằng phần mềm ClustalX2.1. Cây phả hệ thể hiện mối quan hệ di truyền giữa Mẫu nghiên cứu và các loài thuộc chi Streptomyces hiện có trên dữ liệu GenBank được xây dựng bằng phầm mềm MrBayes theo phương pháp Bayesian. 


\subsection{Xác định hoạt độ amylase bằng phương pháp Bernfeld}

Hoạt độ amylase của enzyme ngoại bào từ xạ khuẩn được xác định thông qua lượng đường khử tạo thành sau phản ứng giữa dịch enzyme thô và cơ chất tinh bột $1 \%$. Phương pháp này dựa trên cơ sở sử dụng thuốc thử 3,5-acid dinitrosalicylic (DNS) có màu vàng sau khi cho phản ứng với đường khử (sản phẩm thủy phân của cellulose) sẽ tạo thành 3-amino,5-nitro salicylic acid màu đỏ cam có khả năng hấp thụ cực đại bước sóng $540 \mathrm{~nm}$ [20]. Dịch nuôi cấy xạ khuẩn trong điều kiện thích hợp được thu nhận và loại bỏ tế bào bằng cách ly tâm (13.000 vòng/phút trong 10 phút ở $\left.4^{\circ} \mathrm{C}\right)$ để thu nhận dịch enzyme thô amylase ngoại bào. Dịch enzyme cho phản ứng với dung dịch tinh bột $1 \%$ trong 10 phút và thuốc thử DNS được thêm vào để xác định lượng đường khử được giải phóng. Đơn vị hoạt tính (UI) của amylase được xác định bằng lượng enzyme cần thiết để giải phóng 1 micromole đường khử ở $37^{\circ} \mathrm{C}$ trong 1 phút.

2.5 Khảo sát điều kiện nuôi cấy thích hợp cho sự sinh tổng hợp amylase của xạ khuẩn

Chủng xạ khuẩn được nuôi trong môi trường Gause I lỏng ở $37^{\circ} \mathrm{C}, 150$ vòng/phút trong 4 ngày và được sử dụng như nguồn giống tăng sinh cho các thí nghiệm khảo sát điều kiện sinh tổng hợp enzyme này như ảnh hưởng của nguô̂n cơ chất, nitơ, điều kiện nhiệt độ, $\mathrm{pH}$ khác nhau. Hoạt tính amylase của dịch nuôi cấy xạ khuẩn sau khi loại bỏ tế bào bằng phương pháp ly tâm 13.000 vòng/phút tại $4^{\circ} \mathrm{C}$ sẽ được xác định sau mỗi 24 giờ nuôi cấy bằng phương pháp Bernfeld.

Để khảo sát ảnh hưởng của các nguồn cơ chất, môi trường Gause II với thành phần bao gồm $3,0 \mathrm{~g}$ cao thịt; $5,0 \mathrm{~g}$ pepton; $5,0 \mathrm{~g} \mathrm{NaCl}$; nước cất vừa đủ 1 lít; $\mathrm{pH} 7,2-7,4$ và bổ sung $10,0 \mathrm{~g}$ một trong các cơ chất khác nhau như tinh bột, bột gạo, bột mì, bột bắp. Cơ chất cho kết quả tổng hợp enzyme cao nhất được sử dụng cho các thí nghiệm khảo sát tiếp theo.

Ảnh hưởng của nguồn nitơ lên sự sinh tổng hợp amylase được kiểm tra trong môi trường Gause II với thành phần cacbon cho kết quả cao nhất trong thí nghiệm trên và thay thế nguồn nitơ bằng $5 \mathrm{~g}$ tryptone, cao nấm men, $\mathrm{NaNO}_{3},\left(\mathrm{NH}_{4}\right)_{2} \mathrm{SO}_{4}, \mathrm{NH}_{4} \mathrm{NO}_{3}, \mathrm{NH}_{4} \mathrm{Cl}$, ure.

Nguồn cơ chất và nitơ cho kết quả hoạt tính amylase của dịch nuôi cấy cao nhất sẽ được chọn để tiếp tục khảo sát sự ảnh hưởng của nhiệt độ nuôi cấy lên sự sinh tổng hợp amylase của xạ khuẩn. Chủng xạ khuẩn được nuôi trong môi trường thử nghiệm có nguồn cơ chất và nitơ thích hợp và được nuôi ủ ở các điều kiện nhiệt độ khác nhau $25^{\circ} \mathrm{C}, 30^{\circ} \mathrm{C}, 35^{\circ} \mathrm{C}, 37^{\circ} \mathrm{C}, 40^{\circ} \mathrm{C} \pm 0,1^{\circ} \mathrm{C}$.

Kết quả chọn lọc từ các điều kiện thích hợp về nguồn cơ chất, nitơ phù hợp sẽ được sử dụng trong khảo sát ảnh hưởng của $\mathrm{pH}$ môi trường lên sự sinh tổng hợp amylase của xạ khuẩn. Môi trường thử nghiệm được điều chỉnh ở các giá trị $\mathrm{pH}$ ban đầu khác nhau 4,0;5,0;6,0;7,0;8,0;9,0 $\pm 0,1$ và được nuôi ủ tại nhiệt độ thích hợp đã được chọn lọc.

\subsection{Phương pháp thống kê và xử lý số liệu}

Giá trị kết quả của các thí nghiệm là trung bình của 3 lần lặp lại. Số liệu được tính toán, vẽ biểu đồ trên Microsoft Excel 2013 và được xử lý thống kê bằng phương pháp ANOVA bằng phần mềm Statgraphics Centurion 18.

\section{KẾT QUẢ VÀ THẢO LUẬN}

\subsection{Phân lập và tuyển chọn các chủng xạ khuẩn có hoạt tính amylase}

Các chủng xạ khuẩn được phân lập từ các mẫu đất thu thập từ nhiều địa phương khác nhau thuộc tỉnh Tiền Giang và Bến Tre, trên môi trường Gause $\mathrm{I}$ ở $37^{\circ} \mathrm{C}$ trong 7 ngày. Kết quả phân lập được 23 chủng xạ khuẩn khác nhau có thể sinh trưởng và phát triển trên môi trường chọn lọc và được đặt tên theo thứ tự RB-XK01 đến RB-XK23. Kết quả sàng lọc với dung dịch lugol cho thấy có 6 chủng xạ khuẩn có khả năng hình thành vòng phân giải tinh bột với độ lớn vòng phân giải từ $1,0-2,9 \mathrm{~cm}$. Các chủng xạ khuẩn có khả năng phân giải tinh bột mạnh được thể hiện trong hình 1 và độ lớn vòng phân giải được thể hiện trong bảng 1 . Các chủng vi khuẩn thể hiện độ lớn vòng phân giải nhỏ hơn $1,0 \mathrm{~cm}$ được xem như khả năng sinh tổng hợp amylase ngoại bào không đáng kể (17 chủng).

Bảng 1: Độ lớn vòng phân giải tinh bột của các chủng xạ khuẩn phân lập được

\begin{tabular}{|c|c|c|}
\hline Chủng xạ khuẩn & Nguồn đất phân lập & Độ lớn vòng phân giải A (D-d, cm) \\
\hline RB-XK2 & Tiền Giang & $2,77^{\mathrm{a}} \pm 0,40$ \\
\hline RB-XK3 & Tiền Giang & $2,94^{\mathrm{a}} \pm 0,56$ \\
\hline RB-XK7 & Bến Tre & $1,56^{\mathrm{b}} \pm 0,19$ \\
\hline RB-XK16 & Bến Tre & $1,33^{\mathrm{b}} \pm 0,06$ \\
\hline
\end{tabular}




\begin{tabular}{|c|c|c|}
\hline RB-XK17 & Bến Tre & $2,31^{\mathrm{c}} \pm 0,09$ \\
\hline RB-XK23 & Bến Tre & $1,0^{\mathrm{d}} \pm 0,10$ \\
\hline
\end{tabular}

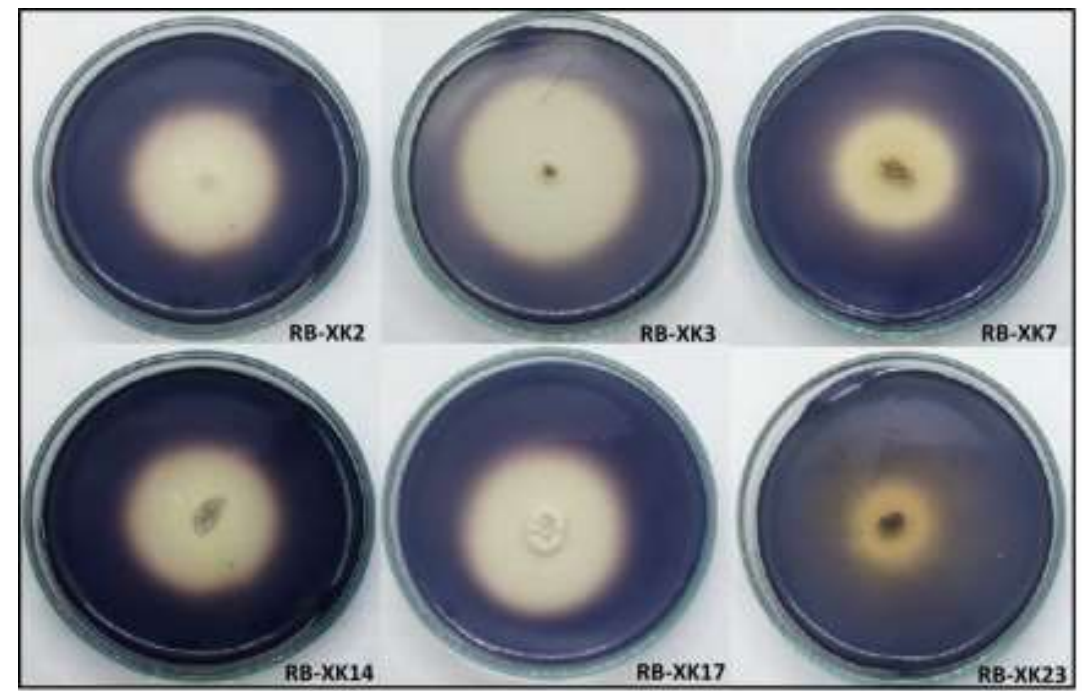

Hình 1. Khả năng sinh amylase của một số chủng xạ khuẩn phân lập được.

Dựa trên kết quả được thể hiện ở bảng 1, trong số 6 chủng xạ khuẩn thể hiện khả năng phân giải tinh bột trong môi trường Gause I thì chủng xạ khuẩn RB-XK3 thấy khả năng sinh tổng hợp amylase ngoại bào tốt nhất với độ lớn vòng phân giải lên đến $2,94 \pm 0,56 \mathrm{~cm}$. Hai chủng xạ khuẩn RB-XK2 và RBXK17 thể hiện hoạt tính phân giải tinh bột cao với độ lớn vòng phân giải tương ứng $2,77 \pm 0,40$ và 2,31 $\pm 0,09 \mathrm{~cm}$, trong khi ba chủng xạ khuẩn còn lại RB-XK7, RB-XK16, RB-XK23 thì có độ lớn vòng phân giải từ $1,01 \pm 0,10$ đến $1,56 \pm 0,19 \mathrm{~cm}$. Kết quả phân tích thống kê cho thấy độ lớn vòng phân giải tinh bột của chủng RB-XK3 không có sự khác biệt có ý nghĩa với chủng RB-XK2, tuy nhiên, kết quả thống kê cũng cho thấy có sự khác biệt đáng kể với các chủng còn lại (ANOVA, $\mathrm{n}=3$, độ tin cậy 95\%). Với độ lớn vòng phân giải $2,94 \pm 0,56 \mathrm{~cm}$, chủng xạ khuẩn RB-XK3 cho thấy khả năng sản sinh amylase ngoại bào cao và cao hơn 8 chủng Streptomyces S1-S8 được phân lập và chọn lọc từ biển có vòng phân giải $0,4-2,0 \mathrm{~cm}$ trong nghiên cứu của Sathya Rengasamy và cộng sự (2018) [16], và tương tự như chủng Streptomyces sp. SLBA-08 được chọn lọc từ 286 chủng xạ khuẩn trong nghiên cứu của Santos và cộng sự (2012) [21]. Như vậy, với sự thể hiện khả năng sinh tổng hợp amylase cao, chủng xạ khuẩn RB-XK3 được chọn làm đối tượng nghiên cứu cho các thí nghiệm khảo sát điều kiện sinh tổng hợp amylase tiếp theo.

\section{7 Đặc điểm hình thái khuẩn lạc, vi thể và định danh xạ khuẩn RB-XK3}

Chủng xạ khuẩn RB-XK3 được kiểm tra các đặc điểm đại thể về hình thái khuẩn lạc trên môi trường Gause I sau 10 ngày nuôi ủ. Khuẩn lạc của RB-XK3 tròn, có kích thước $0,4-0,6 \mathrm{~cm}$, màu trắng đục, bờ không đều, tâm màu vàng nhạt, khuẩn ty cơ chất bám sâu vào bề mặt thạch, khuẩn ty khí sinh nằm sát bề mặt môi trường (hình $2 \mathrm{~A}$ ). Kết quả vi thể trên tiêu bản phòng ẩm được quan sát dưới kính hiển vi cho thấy cuống sinh bào tử của $\mathrm{RB}-\mathrm{XK} 3$ phân nhánh, có dạng xoắn lò xo, với bào tử hình thành trên các cuống sinh bào tử ở dạng chuỗi dài (hình $2 \mathrm{~B}-\mathrm{C}$ ). 

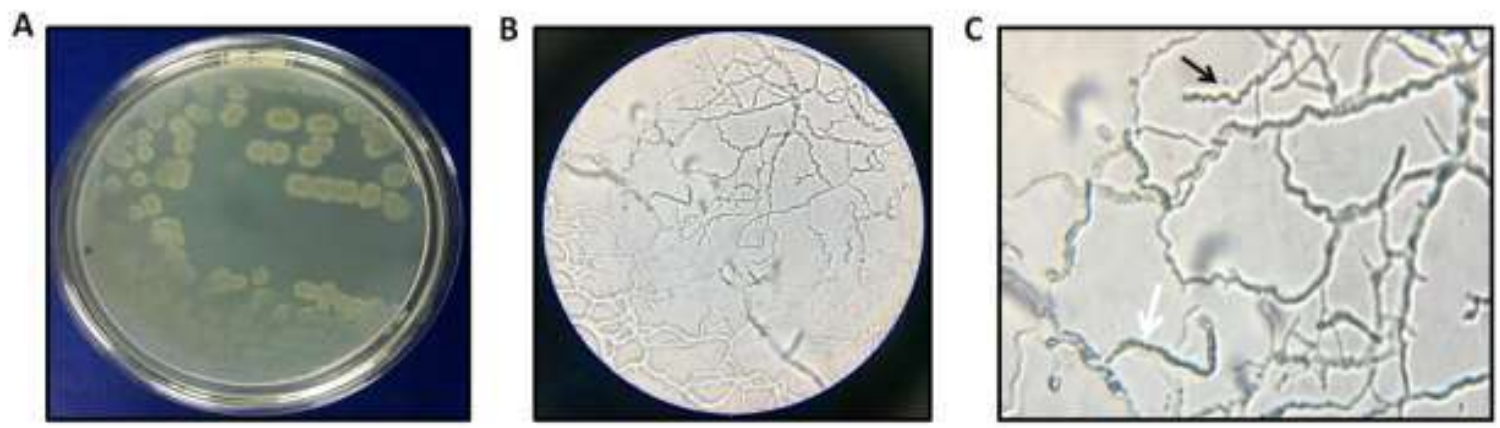

Hình 2. Hình thái đại thể và vi thể của xạ khuẩn RB-XK3. (A) Hình thái khuẩn lạc trên môi trường Gause I sau 3 ngày nuôi ủ ở $37^{\circ} \mathrm{C}$. (B) Hình ảnh vi thể ở độ phóng đại X1000. (C) Hình ảnh phóng đại của cuống sinh bào tử (mũi tên đen) và chuỗi bào tử (mũi tên trắng).

Bên cạnh đó, một phần trình tự đoạn gen mã hóa cho16S-rRNA (900bp) của xạ khuẩn RB-XK3 cũng được kiểm tra với trình tự mồi như trên và so sánh với ngân hàng dữ liệu trên NCBI. Kết quả cho thấy gen mã hóa cho 16S-rRNA của chủng RB-XK3 có sự tương đồng với các chủng xạ khuẩn thuộc chi Streptomyces. Dựa trên các kết quả thu được, cây phả hệ của chủng xạ khuẩn RB-XK3 với các loài gần được xây dựng và được xác định chủng xạ khuẩn RB-XK3 thuộc chi Streptomyces (hình 3).

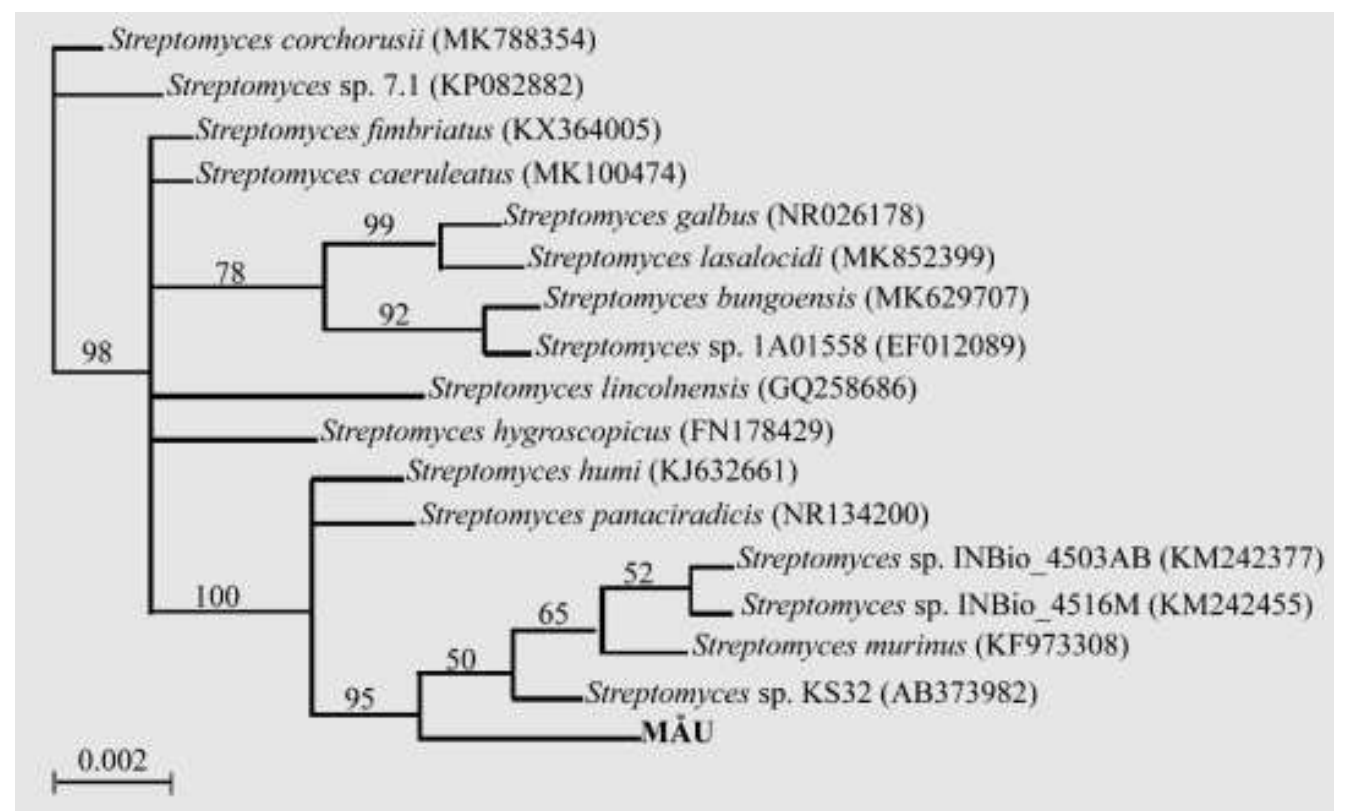

Hình 3. Cây phả hệ thể hiện mối quan hệ di truyền (vùng vùng trình tự $16 \mathrm{~S}$ ribosomal RNA) giữa mẫu nghiên cứu và các taxa từ dữ liệu $\mathrm{NCBI}$, được xây dựng bằng phần mềm MrBayes theo phương pháp Bayesian với các nhánh có giá trị bootstrap $>50 \%$ được giữ lại.

\section{8 Ảnh hưởng của nguồn cơ chất lên sự sinh tổng hợp amylase của xạ khuẩn RB-XK3}

Tương tự như các loại vi sinh vật khác, sự tổng hợp enzyme ngoại bào của xạ khuẩn cũng chịu ảnh hưởng trực tiếp bởi các cơ chất tương ứng có trong môi trường. Do đó, chúng tôi tiến hành khảo sát ảnh hưởng của các cơ chất tinh bột khác nhau (tinh bột tan, bột gạo, bột mì, bột bắp) lên quá trình sinh tổng hợp amylase ngoại bào của xạ khuẩn RB-XK3. Dịch nuôi cấy xạ khuẩn sau mỗi 24 giờ nuôi ủ được thu nhận và kiểm tra hoạt tính amylase theo phương pháp Bernfeld. Kết quả ảnh hưởng của các cơ chất tinh bột khác nhau theo thời gian lên sự sinh tổng hợp amylase được trình bày ở hình 4. 

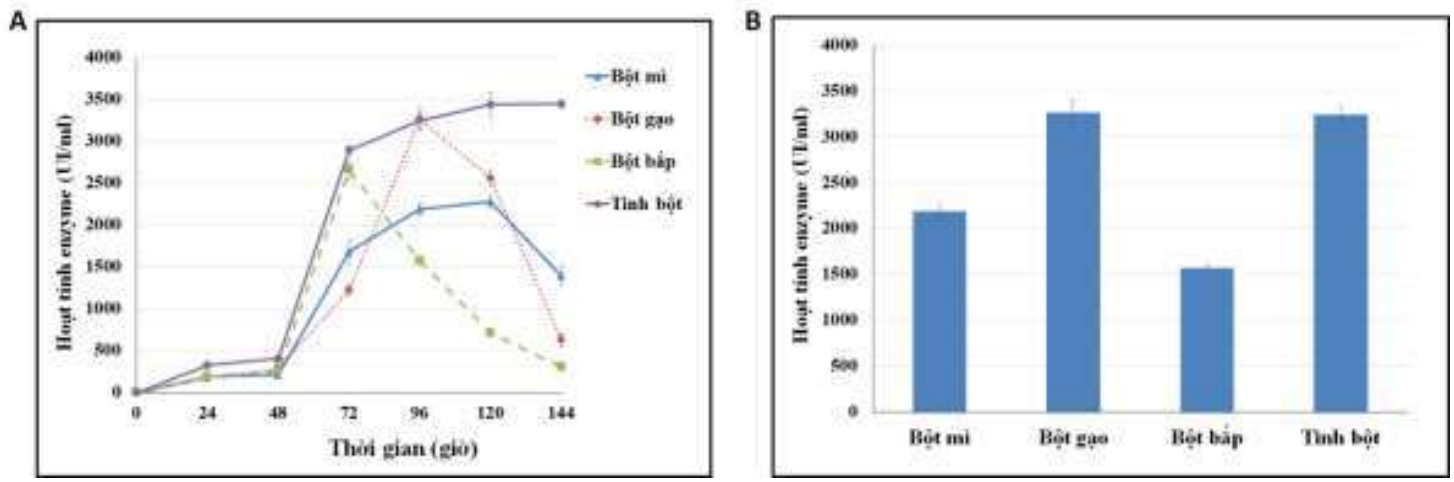

Hình 4. Ảnh hưởng của các nguồn cơ chất lên sự tổng hợp amylase của xạ khuẩn RB-XK3 theo thời gian (A) và tại thời điểm 96 giờ nuôi cấy $(\mathrm{B})$

Kết quả cho thấy chủng xạ khuẩn RB-XK3 đều có khả năng sinh tổng hợp amylase trong môi trường Gause II với các cơ chất bổ sung là tinh bột, bột gạo, bột mì, bột bắp với các mức độ khác nhau (hình 4A). Trong 48 giờ nuôi ủ ban đầu, RB-XK3 thể hiện sự tổng hợp enzyme không đáng kể. Sau 72 giờ nuôi ủ, cả bốn loại cơ chất đều cho thấy sự sinh tổng hợp amylase vượt trội, nguồn cơ chất tinh bột và bột bắp cho kết quả tốt nhất với hoạt tính là $2895 \pm 56,5 \mathrm{UI} / \mathrm{ml}$ và $2660 \pm 97,8 \mathrm{UI} / \mathrm{ml}$, trong khi hoạt tính amylase thu được trong điều kiện bột gao và bột mì chỉ đạt $1221 \pm 64,2 \mathrm{UI} / \mathrm{ml}$ và $1683 \pm 147,6 \mathrm{UI} / \mathrm{ml}$. Tuy nhiên, sau thời gian nuôi ủ là 96 giờ, hoạt tính amylase trong môi trường bổ sung cơ chất là bột gạo cho kết quả tăng cao với $3266 \pm 138,1 \mathrm{UI} / \mathrm{ml}$, tương tự như hoạt tính đạt được trong môi trường có nguồn cơ chất tinh bột $3248 \pm 91,9 \mathrm{UI} / \mathrm{ml}$, trong khi các môi trường có cơ chất là bột mì và bột bắp cho kết quả chỉ đạt được $2189 \pm 74,2 \mathrm{UI} / \mathrm{ml}$ và $1574 \pm 24,3 \mathrm{UI} / \mathrm{ml}$ (hình $4 \mathrm{~B}$ ). Sự gia tăng thời gian nuôi ủ cho thấy sự giảm hoạt tính amylase của dịch nuôi cấy, ngoài trừ môi trường có nguồn cơ chất là tinh bột, nguyên nhân có thể do các nguồn cơ chất này không phải là môi trường thích hợp cho sự sinh trưởng của xạ khuẩn, do đó, sự hạn chế về mật độ xạ khuẩn cũng sẽ hạn chế sự sinh tổng hợp enzyme của vi sinh vật này. Bên cạnh đó, kết quả phân tích thống kê cho thấy có sự khác biệt đáng kể của nguồn cơ chất tinh bột với các nguồn cơ chất bột bắp, bột mì và không có sự khác biệt đối với nguồn cơ chất bột gạo lên sự sinh tổng hợp amylase của chủng xạ khuẩn RB-XK3 sau 96 giờ nuôi ủ (ANOVA, n=3, độ tin cậy 95\%). Do đó, để ổn định quá trình sinh tổng hợp enzyme, tinh bột được chọn làm cơ chất cho các thí nghiệm khảo sát tiếp theo lên quá trình sinh tổng hợp amylase của xạ khuẩn RB-XK3 với thời gian nuôi ủ là sau 96 giờ.

\section{9 Ảnh hưởng của nguồn nitơ lên sự sinh tổng hợp amylase của xạ khuẩn RB-XK3}

Bên cạnh nguồn cơ chất cacbon, nitơ là thành phần không thể thiếu trong sự sinh trưởng và phát triển của các loại sinh vật. Sự sinh tổng hợp enzyme ngoại bào của các vi sinh vật cũng bị ảnh hưởng bởi thành phần này. Do đó, để xác định ảnh hưởng của nitơ lên sự sinh tổng hợp amylase của xạ khuẩn RB-XK3, chúng tôi tiến hành khảo sát các nguồn nitơ khác nhau là $\left(\mathrm{NH}_{4}\right)_{2} \mathrm{SO}_{4}, \mathrm{NH}_{4} \mathrm{NO}_{3}, \mathrm{NH}_{4} \mathrm{Cl}, \mathrm{NaNO}_{3}$, ure, cao nấm men, tryptone lên sự sản sinh amylase ngoại bào của xạ khuẩn. Hoạt tính amylase của dịch nuôi cấy được kiểm tra sau mỗi 24 giờ nuôi ủ và được thể hiện ở hình 5 .
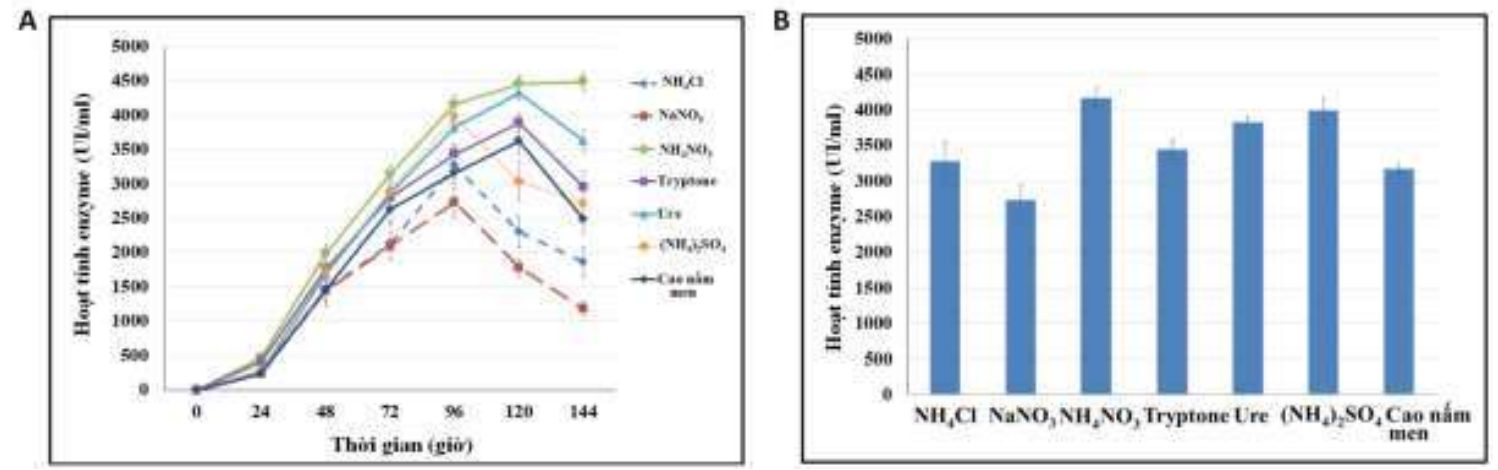

Hình 5. Ảnh hưởng của các nguồn nitơ lên sự tổng hợp amylase của xạ khuẩn RB-XK3 theo thời gian (A) và tại thời điểm 96 giờ nuôi cấy $(\mathrm{B})$ 
Hoạt tính amylase của chủng RB-XK3 được ghi nhận cho kết quả cao nhất trong môi trường nuôi cấy có bổ sung nguồn nitơ $\mathrm{NH}_{4} \mathrm{NO}_{3}$ với 4161,9 $\mathrm{IU} / \mathrm{ml} \pm 140,2 \mathrm{UI} / \mathrm{ml}$ sau 96 giờ lên men và duy trì hoạt tính cao nhất theo trong khoảng thời gian lên men tiếp theo đến 144 giờ (hình $5 \mathrm{~A}$ ). Hoạt tính amylase trong các môi trường lên men có bổ sung $\left(\mathrm{NH}_{4}\right)_{2} \mathrm{SO}_{4}$ và ure lần lượt được ghi nhận là $3980,9 \pm 185,4 \mathrm{UI} / \mathrm{ml}$ và $3827,1 \pm 84,1 \mathrm{UI} / \mathrm{ml}$ tại thời điểm lên men là 96 giờ và chênh lệch không đáng kể khi so sánh với môi trường lên men có chứa $\mathrm{NH}_{4} \mathrm{NO}_{3}$ (ANOVA, $\mathrm{n}=3$, độ tin cậy $95 \%$ ). Tuy nhiên, sau thời gian tiếp tục lên men đến 144 giờ thì hoạt tính amylase giảm và cho thấy có sự ảnh hưởng của các sản phẩm trao đổi thứ cấp trong môi trường lên men lên hoạt tính của amylase sinh tổng hợp từ xạ khuẩn RB-XK3. Ngoài ra, hoạt tính amylase của dung dịch enzyme trong các môi trường bổ sung các nguồn nitơ khác cũng được kiểm tra, hoạt tính thể hiện thấp hơn với các giá trị lần lượt là 3275,2 $\pm 267,4 \mathrm{IU} / \mathrm{ml}, 2732,4 \pm 209,3$ $\mathrm{IU} / \mathrm{ml}, 3438,1 \pm 140,2 \mathrm{IU} / \mathrm{ml}, 3166,7 \pm 85,3 \mathrm{IU} / \mathrm{ml}$ tương ứng với $\mathrm{NH}_{4} \mathrm{Cl}, \mathrm{NaNO}_{3}$, Tryptone, cao nấm men (hình 5B). Sự gia tăng thời gian nuôi cấy đến 144 giờ cũng ảnh hưởng đến chất lượng của dung dịch enzyme trong các môi trường lên men này và cho thấy hoạt tính amylase giảm mạnh so với hoạt tính được ghi nhận trước đó. Căn cứ trên các kết quả thu nhận được, nguồn nitơ $\mathrm{NH}_{4} \mathrm{NO}_{3}$ được chọn bổ sung vào môi trường sinh tổng hợp amylase của xạ khuẩn $\mathrm{RB}-\mathrm{XK} 3$ với thời gian lên men được xác định là sau 96 giờ.

\subsection{0 Ảnh hưởng của điều kiện nhiệt độ lên sự sinh tổng hợp amylase của xạ khuẩn RB-XK3}

Nhiệt độ lên men là một trong những yếu tố ảnh hưởng đến hoạt tính enzyme cũng như khả năng sản sinh enzyme của các vi sinh vật, đặc biệt là xạ khuẩn. Ảnh hưởng của nhiệt độ lên sự sinh tổng hợp amylase được kiểm tra trong môi trường Gause II với nguồn nitơ là $\mathrm{NH}_{4} \mathrm{NO}_{3}$ tại các điều kiện nhiệt độ khác nhau $\left(25,30,35,37,40^{\circ} \mathrm{C}\right), 150$ vòng/phút. Hoạt tính amylase trong các dung dịch nuôi cấy tại các nhiệt độ khác nhau được kiểm tra tương tự như các thí nghiệm trên sau mỗi 24 giờ cho đến khi hoạt tính không tăng đáng kể và kết quả được thể hiện ở hình 5 bên dưới.

Chủng xạ khuẩn RB-XK3 thể hiện hoạt tính khác nhau tại điều kiện nhiệt độ khác nhau sau 144 giờ lên men (hình $6 \mathrm{~A}$ ), trong đó hoạt tính cao nhất là điều kiện nhiệt độ $37^{\circ} \mathrm{C}$ với $4478,6 \pm 42,0 \mathrm{UI} / \mathrm{ml}$ trong khi các điều kiện nhiệt độ khác thể hiện thấp hơn tương ứng là $380,0 \pm 24,3 \mathrm{UI} / \mathrm{ml}, 633,3 \pm 70,1 \mathrm{UI} / \mathrm{ml}$, $841,4 \pm 64,2 \mathrm{UI} / \mathrm{ml}, 2542,4 \pm 85,3 \mathrm{UI} / \mathrm{ml}$ ở các nhiệt độ $25^{\circ} \mathrm{C}, 30^{\circ} \mathrm{C}, 35^{\circ} \mathrm{C}, 40^{\circ} \mathrm{C}$. So sánh hoạt tính thể hiện theo thời gian ở các nhiệt độ khác nhau, kết quả cho thấy khả năng sinh tổng hợp amylase của chủng xạ khuẩn RB-XK3 không thích hợp ở các nhiệt độ thấp như $25^{\circ} \mathrm{C}, 30^{\circ} \mathrm{C}$ trong khi nhiệt độ ấm $35^{\circ} \mathrm{C}-40^{\circ} \mathrm{C}$ thích hợp cho sự tổng hợp amylase hơn. Điều này cũng phù hợp cho đặc tính sinh trưởng và phát triển ưa nhiệt của các chủng xạ khuẩn.

Tại các điều kiện $35^{\circ} \mathrm{C}, 37^{\circ} \mathrm{C}, 40^{\circ} \mathrm{C}$, sau 96 giờ lên men, hoạt tính amylase thể hiện tương ứng là $3429,0 \pm 78,0 \mathrm{UI} / \mathrm{ml}, 3600,9 \pm 28,0 \mathrm{UI} / \mathrm{ml}, 3492,4 \pm 85,3 \mathrm{UI} / \mathrm{ml}$ và kết quả phân tích thống kê cho thấy không có sự khác biệt đáng kể về sự sinh tổng hợp amylase ở các điều kiện nhiệt độ này sau 96 giờ nuôi ủ (ANOVA, n=3, độ tin cậy 95\%) (hình 6B). Tuy nhiên, khi thời gian nuôi ủ tăng lên, hoạt tính amylase trong các điều kiện $35^{\circ} \mathrm{C}$ và $40^{\circ} \mathrm{C}$ giảm, trong khi hoạt tính amylase tại $37^{\circ} \mathrm{C}$ thì không có xu hướng giảm và tiếp tục tăng nhẹ. Kết quả này có thể là nguyên nhân của sự giảm khả năng sinh trưởng của xạ khuẩn trong môi trường nhiệt độ thấp, hoặc do ảnh hưởng của các chất trao đổi thứ cấp của xạ khuẩn trong quá trình sinh trưởng hình thành. Kết quả tương tự cũng được quan sát thấy trong sự sinh tổng hợp amylase của xạ khuẩn Streptomyces spp. PDS1 trong nghiên cứu của Ragunathan và cộng sự (2013) [17]. Ngoài ra, kết quả cho thấy chủng xạ khuẩn RB-XK3 này sinh tổng hợp amylase tốt sau 96 giờ nuôi ủ tương tự như các dòng xạ khuẩn Streptomyces S1-S8 trong nghiên cứu của Sathya Rengasamy và cộng sự (2018) [16], chủng Streptomyces gancidius_ASD-KT852565 trong nghiên cứu của Ashwini Krishnan và cộng sự (2015) [11] và nhanh hơn chủng Streptomyces spp. PDS1 với thời gian thích hợp là 120 giờ (Ragunathan và cộng sự-2013) [17], trong khi chủng Streptomyces sp. D1 có thời gian lên men tạo amylase thích hợp là 10 ngày trong nghiên cứu của Chakraborty và cộng sự (2009) [22]. Dựa vào các kết quả thu nhận được, nhiệt độ $37^{\circ} \mathrm{C}$ được chọn cho sự sinh tổng hợp của amylase của xạ khuẩn RB-XK3 và thời gian nuôi ủ được xác định tương tự như các kết quả nghiên cứu trước là sau 96 giờ. 

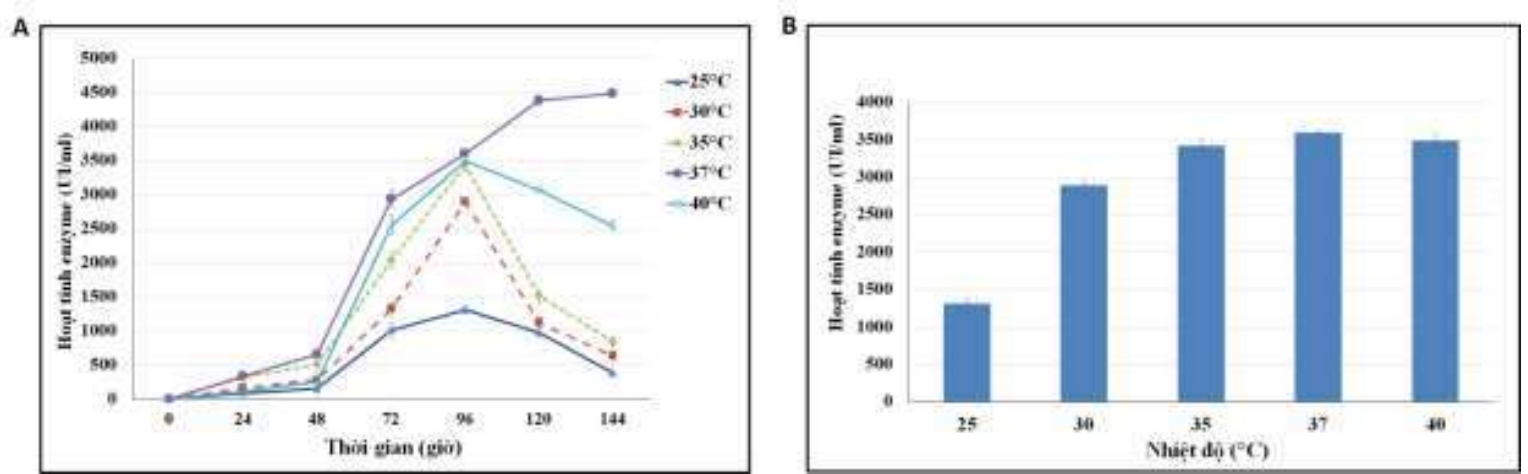

Hình 6. Ảnh hưởng của điều kiện nhiệt độ khác nhau lên sự sinh tổng hợp amylase của xạ khuẩn RB-XK3 theo thời gian $(\mathrm{A})$ và tại thời điểm 96 giờ nuôi cấy $(\mathrm{B})$

\section{6. Ảnh hưởng của pH môi trường lên sự sinh tổng hợp amylase của xạ khuẩn RB-XK3}

Ngoài việc chịu ảnh hưởng bởi các thành phần cơ chất cacbon, nitơ, và điều kiện nhiệt độ môi trường, sự sinh tổng hợp amylase ngoại bào của các vi sinh vật cũng bị ảnh hưởng bởi các yếu tố $\mathrm{pH}$ của môi trường cấy. Để khảo sát ảnh hưởng của yếu tố $\mathrm{pH}$ lên sự sinh tổng hợp amylase của xạ khuẩn RB-XK3, môi trường Gause II với thành phần cơ chất tinh bột và nguồn nitơ $\mathrm{NH}_{4} \mathrm{NO}_{3}$ được điều chỉnh ở các giá trị $\mathrm{pH}$ ban đầu khác nhau 4,0,5,0,6,0,7,0,8,0,9,0 00,1 và xạ khuẩn được nuôi cấy tại nhiệt độ $37^{\circ} \mathrm{C}$ trong điều kiện lắc 150 vòng/phút. Dung dịch enzyme được thu nhận và kiểm tra hoạt tính sau mỗi 24 giờ nuôi cấy.
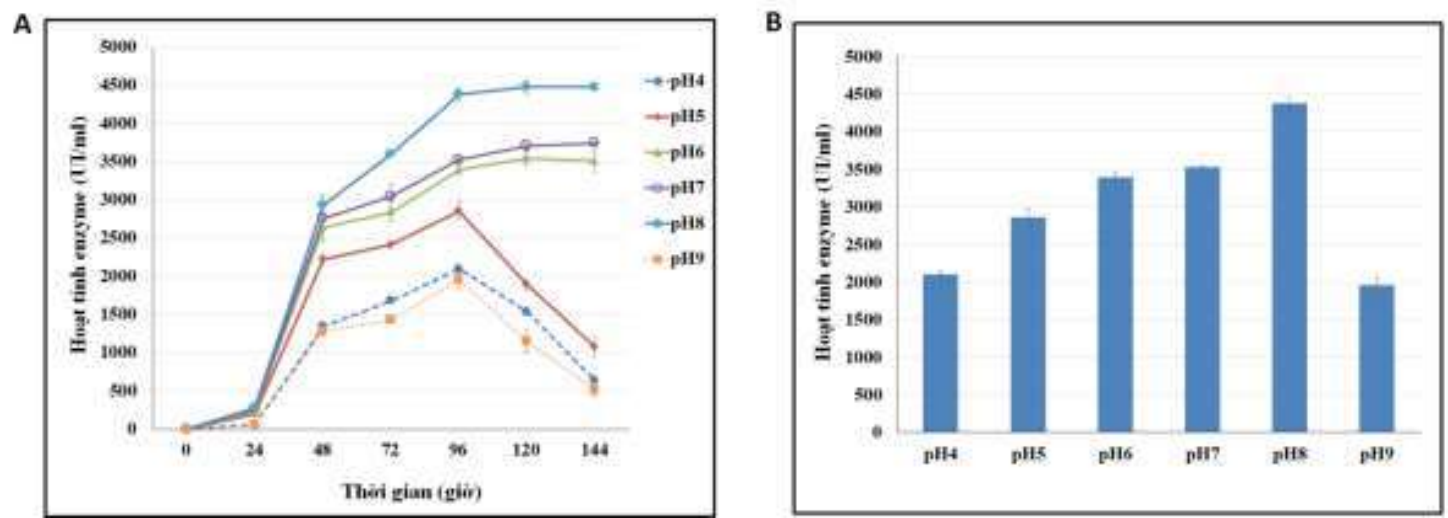

Hình 7. Ánh hưởng của điều kiện $\mathrm{pH}$ khác nhau lên sự sinh tổng hợp amylase của xạ khuẩn RB-XK3 theo thời gian $(\mathrm{A})$ và tại thời điểm 96 giờ nuôi cấy $(\mathrm{B})$.

Kết quả thể hiện ở hình 6 cho thấy chủng xạ khuẩn RB-XK3 có khả năng tổng hợp amylase tốt nhất trong môi trường nuôi cấy có giá trị $\mathrm{pH}$ ban đầu trong khoảng $6,0-8,0$ và mạnh nhất ở $\mathrm{pH} 8,0$ với hoạt tính $4379,0 \pm 78,0 \mathrm{UI} / \mathrm{ml}$ trong khi hoạt tính ở điều kiện $\mathrm{pH} 6,0$ và 7,0 là $3392,9 \pm 64,2 \mathrm{UI} / \mathrm{ml}$ và $3528,6 \pm$ 24,3 UI/ml sau 96 giờ nuôi ủ. Kết quả phân tích thống kê cho thấy không có sự khác biệt đáng kể về sự sinh tổng hợp amylase sau 96 giờ với 120 và 144 giờ nuôi ủ (ANOVA, n=3, dộ tin cậy $95 \%$ ) (hình $7 \mathrm{~A}$ ). Bên cạnh đó, hoạt tính enzyme thu nhận ở các môi trường nuôi cấy có điều kiện $\mathrm{pH} 4,0,5,0$ và 9,0 thể hiện hoạt tính thấp và chỉ đạt 2099,0 $\pm 61,1 \mathrm{UI} / \mathrm{ml}$ ở $\mathrm{pH} 4,0,2859,0 \pm 114,7 \mathrm{UI} / \mathrm{ml}$ ở $\mathrm{pH} 5,0$ và 1954,3 \pm 121,4 UI/ml trong điều kiện $\mathrm{pH} 9,0$ sau 96 giờ nuôi ủ, đồng thời hoạt tính giảm mạnh theo thời gian nuôi ủ và chỉ đạt dưới 1076,7 UI/ml sau 144 giờ nuôi ủ (hình $7 \mathrm{~A}$ ). Ngoài ra, sự giảm hoạt tính enzyme trong các điều kiện $\mathrm{pH}$ acid mạnh $(4,0-5,0)$ hoặc $\mathrm{pH}$ kiềm $(9,0)$ do điều kiện bất lợi của môi trường ảnh hưởng đến khả năng sinh trưởng và phát triển của xạ khuẩn, từ đó ảnh hưởng đến khả năng sinh tổng hợp enzyme của xạ khuẩn. Ngoài ra điều kiện $\mathrm{pH}$ không phù hợp cũng sẽ ảnh hưởng đến sự ổn định cấu trúc của enzyme và làm giảm hoạt tính của enzyme. Kết quả khảo sát cho thấy sự sinh tổng hợp amylase của RB-XK3 thích hợp trong điều kiện $\mathrm{pH}$ trung tính, acid yếu hoặc kiềm yếu $(6,0-8,0)$, kêt quả phân tích thống kê cho thấy có sự khác biệt đáng kể về hoạt tính amylase thu nhận tại $\mathrm{pH} 8,0$ với các điều kiện $\mathrm{pH}$ 6,0 và 7,0 sau 96 giờ nuôi ủ (ANOVA, n=3, độ tin cậy 95\%) (hình 7B). Như vậy, chủng xạ khuẩn RBXK3 thích hợp sinh tổng hợp amylase trong môi trường có $\mathrm{pH}$ kiềm, trong khi phần lớn các chủng xạ khuẩn được nghiên cứu trước đây thể hiện tốt điều kiện $\mathrm{pH}$ trung tính 7,0 như chủng Streptomyces sp. 
SLBA-08, chủng Streptomyces spp. PDS1 trong các nghiên cứu tương ứng của Santos và cộng sự (2012) [21], Ragunathan và cộng sự (2013) [17], hoặc chủng xạ khuẩn Streptomyces gancidius_ASD-KT852565 được phân lập từ biển trong nghiên cứu của Ashwini Krishnan và cộng sự (2015) [11]. Ngoài ra, sự sinh tổng hợp amylase từ các chủng xạ khuẩn ưa kiềm cũng được ghi nhận trong nghiên cứu của Chakraborty S và cộng sự (2012) [23].

\section{KẾT LUẬN}

Từ các nguồn mẫu đất khác nhau, 23 chủng xạ khuẩn đã được phân lập và kiểm tra sự sinh tổng hợp amylase ngoại bào của các chủng xạ khuẩn này. Chủng xạ khuẩn RB-XK3 thể hiện sự sinh tổng hợp amylase cao nhất và được định danh bằng phân tích trình tự $16 \mathrm{~S}$ rRNA. So sánh với ngân hàng dữ liệu NCBI, chủng RB-XK3 được xác định thuộc chi Streptomyces và loài Streptomyces canus. Điều kiện sinh tổng hợp amylase của chủng xạ khuẩn đã được kiểm tra và xác định. Chủng xạ khuẩn RB-XK3 thể hiện sự tổng hợp enzyme tốt nhất trong môi trường Gause II có bổ sung $1 \%$ cơ chất tinh bột, $0,5 \% \mathrm{NH}_{4} \mathrm{NO}_{3}$. Thời gian thích hợp cho sự sinh tổng hợp enzyme cũng được kiểm tra trong các điều kiện khảo sát tương ứng và xác định được thời gian tối thích là 96 giờ nuôi ủ trong điều kiện nhiệt độ $37^{\circ} \mathrm{C}$ và $\mathrm{pH}$ môi trường thích hợp là 8,0 . Khả năng hoạt động tốt của xạ khuẩn RB-XK trong môi trường $\mathrm{pH} 8,0$ cho thấy tiềm năng cao trong việc ứng dụng tạo các chế phẩm sinh học để xử lý các chất thải tinh bột hoặc giặt tẩy các chất bẩn có nguồn gốc từ tinh bột trong điều kiện kiềm hóa một cách hiệu quả, đặc biệt hỗ trợ trong việc phát triển bền vững của môi trường và đời sống.

LỜI CẢM ONN Kết quả nghiên cứu này là một phần trong đề tài nghiên cứu khoa học cấp trường "Tuyển chọn xạ khuẩn và phân tích đặc tính của hệ enzyme amylase ngoại bào từ xạ khuẩn" (mã số 184.TP13) được hồ trợ kinh phí từ trường Đại học Công nghiệp thành phố Hồ Chí Minh. Do đó, chúng tôi xin chân thành cảm ơn trường Đại học Công nghiệp thành phố Hồ Chí Minh đã hỗ trợ cho các thí nghiệm trong đề tài nghiên cứu khoa học này.

\section{TÀI LIỆU THAM KHẢO}

1. Rajagopalan G, K.C., Alpha amylase production from catabolic depressed Bacillus subtilis KCC103 utilizing sugarcane bagasse hydrolysate. Bioresource Technology, 2008. 99: p. 3044-3050.

2. Reddy NS, N.A., Sambasiva Rao KRS., An overview of the microbial amylase family. . African Journal of Biotechnology, 2003. 2: p. 645-648.

3. Gupta R, G.P., Mohapatra H, Goswami VK, Chauhan B., Microbial amylases a biotechnological perspective. Process Biochemistry, 2003. 38: p. 1599-1616.

4. A. Pandey, P.N., C. R. Soccol, V. T. Soccol, D. Singh, and R.Mohan, Advances in microbial amylases. Biotechnology and Applied Biochemistry, 2000. 31: p. 135-152.

5. Salma Mukhtar, A.Z., Dalaq Aiysha, Kauser Abdulla Malik and Samina Mehnaz, Actinomycetes: A Source of Industrially Important Enzymes. Journal of Proteomics \& Bioinformatics, 2017. 10: p. 316-319.

6. $\quad$ Kira O, C.U., Arikan B, Effects of carbon sources and various chemicals on production of a novel amylase from a thermophilic Bacillus sp. K-12. Enzyme 2004. 29: p. 99-103.

7. Q. D. Nguyen, J.M.R.-S., M. Claeyssens, I. Stals, and Á. Hoschke, Purification and characterisation of amylolytic enzymes from thermophilic fungus Thermomyces lanuginosus strain ATCC 34626. Enzyme and Microbial Technology,, 2002. 31: p. 345-352.

8. Pandey A, S.C., Mitchell D. , New developments in solid state fermentation: Bioprocess and products. Process Chemistry, 2000. 35: p. 1153-1169.

9. Van der Maarel J.M., V.d.V.B., Uitdehaag J.C., Leemhuis H., Dijkhuizen L., Properties and applications of starch converting enzymes of the alfa amylase family. Journal of Bacteriology, 2002. 94: p. 137-155. 
10. Shafiei M., Z.A.A., Amoozegar M.A., Purification and characterization of an organic-solvent-tolerant halophilic a-amylase from the moderately halophilic Nesterenkonia sp. strain $F$. . Journal of Industrial Microbiology and Biotechnology, 2011. 38: p. 275-281.

11. Ashwini Krishnan, S.S.K., Optimization of alpha amylase extracted from marine actinomycetes Streptomyces gancidicus_ASD-KT852565. International Research Journal of Pharmacy, 2015. 6: p. 729735.

12. Abdullah R, S.N., Iqtedar M, Naz S, Iftikhar T., Optimization of cultural conditions for the production of alphaamylase by Aspergillus niger (BTM-26) in solid state fermentation. Pakistan Journal of Botany, 2014. 46.(1071-1078).

13. Bull AT, S.J., Ward AC, Goodfellow M. , Marine actinobacteria; perspectives, challenges, future directions. Antonie Van Leeuwehoek, 2005. 87: p. 65-79.

14. Sreejetha M, D., Veena S, Kokati Venkata BR., The bioactive potential of Streptomyces variabilis-DV-35 isolated from Thottada Marine sediments, Kannur, Kerala. . Asian Journal of Pharmaceutical and Clinical Research, 2016. 9: p. 67-71.

15. Kamjam M, S.P., Deng Z, Hong K (2017) . 8: 760, Deep Sea Actinomycetes and Their Secondary Metabolites. Frontier in Microbiology, 2017. 8: p. 760.

16. Sathya Rengasamy, U.t., Isolation, screening and determination of a-amylase activity from marine Streptomyces species International Journal of Pharmacy and Pharmaceutical Sciences, 2018. 10: p. 122127.

17. Padhmadas, R.R.a.R., Production, purification and characterization of - amylase using Streptomyces spp. PDS1 and Rhodococcus spp. Isolated from Western Ghats. 2013. 2: p. 206-214.

18. Tanupriya Ojha, K.D., Anjulata Vishwakarma, Production of amylase and lipase enzymes from actinomycetes. World Journal of Pharmaceutical Sciences, 2016. 4: p. 353-356.

19. Renu Singh, V.K., and Vishal Kapoor, Partial Purification and Characterization of a Heat Stable aAmylase from a Thermophilic Actinobacteria, Streptomyces sp. MSC702. Hindawi Publishing Corporation Enzyme Research, 2014. 2014: p. 1-8.

20. Bernfeld, P., Amylase, $\alpha$ and $\beta$. Methods in Enzymology, 1955. 1: p. 149-158.

21. Édilla Ribeiro dos Santos, Z.N.S.T., Núria Mariana Campos, Diogo Angeli Jacinto de Souza, Aline Simões da Rocha Bispo and Rodrigo Pires do Nascimento, Production of a-Amylase from Streptomyces sp. SLBA08 Strain Using Agro-Industrial By-Products. Brazilian archives of Biology and Technology, 2012. 55: p. $793-800$.

22. Chakraborty S, K.A., Kokare C, Mahadik K, Chopade B., Isolation and characterization of novel aamylase from marine Streptomyces sp. D1. Journal of Molecular Catalysis B: Enzymatic, 2009. 58: p. 1723.

23. Chakraborty S, R.G., Khopade A, Mahadik K, Kokare C et al., Study on calcium ion independent aamylase from halo-alkaliphilic marine Streptomyces strain A3. Indian Journal Biotechnology, 2012. 11: p. 427-437. 